\title{
A fehérje-ciklodextrin kölcsönhatás terápiás és diagnosztikai jelentősége
}

\author{
SZENTE Lajos \\ CycloLab Ciklodextrin Kutató-fejlesztö Kft. Illatos út 7, 1097 Budapest
}

\section{Bevezetés}

A ciklodextrinek gyürü alakú szénhidrátmolekulák, melyek három méretben $(6,7$ és 8 tagú alfa-, béta- és gamma-ciklodextrin) megtalálhatók a természetben is. A növekvő igények miatt ma már több tízezer tonnát gyártanak évente a természetes ciklodextrinekböl, és egyre nagyobb mennyiséget a legfontosabb származékokból, így a hidroxipropil-, random metil- és szulfobutil-bétaciklodextrinből (HPBCD, RAMEB és SBEBCD) is.

Az elmúlt csaknem 40 év alatt a ciklodextrin (CD) technológia a korszerü ipar szinte minden területén talált gyakorlati alkalmazást. A ciklodextrin-tartalmú termékekből jelenleg több mint 60 humán gyógyszer, 10 állatgyógyászati készítmény és több száz élelmiszeripari-, kozmetikai- és háztartás-vegyipari termék található a piacon.

E termékek közös sajátsága, hogy bennük a ciklodextrinek, csupán segédanyagok, kapszulázó ágensek, a termékek minőségének javítására, egyes alkotóinak stabilizálására, vízoldékonyságuk, felszívódásuk, biológiai hasznosulásuk fokozására szolgálnak. Napjainkig a ciklodextrinek által kapszulázott hatóanyagok nagy része természetes és szintetikus kismolekula volt, ezek molekulatömege a 200-700 Dalton közötti tartományba esett.

A korszerü biotechnológiai eljárásokkal sejt- és szövetkultúrákban termelt biológiai hatóanyagok mind molekuláris méretük, mind molekulatömegük tekintetében jelentősen eltérnek a fent említett kis molekulás hatóanyagoktól. A terápiás hatású fehérjék molekulatömege már a 2000-300.000 Dalton tartományba esik. Ezen érzékeny makromolekulák sajátos, olykor kiszámíthatatlanul változó térszerkezete, molekulafelszíni polaritási viszonyaik miatt a ciklodextrinekkel történő egyszerü „host-guest” (gazda-vendég) típusú kölcsönhatásuk tanulmányozása a szokásos analitikai módszerekkel nehezen végezhető. Nem meglepő tehát, hogy a ciklodextrinek irodalma, a napjainkig közölt kb. 4500 fehérje-peptid tárgyú közlemény ellenére, a ciklodextrinek hatása tekintetében nem mutat egységes képet. Számos olykor egymásnak ellentmondó - eredmény miatt is nehéz általános következtetéseket levonni a ciklodextrin-fehérje kölcsönhatás nyújtotta lehetőségekről. Ennek egyik feltételezhető oka, mely az irodalom tüzetes átnézésekor derül ki, hogy több, egyébként színvonalas közleményben, a szerzők az alkalmazott ciklodextrinek típusát nem kellően definiálták. Egyes szerzők pl. béta-ciklodextrinnek nevezik a származékolatlan béta-ciklodextrint (helyesen), éppúgy, mint a metil-béta-ciklodextrint, a szulfobutiléter-bétaciklodextrint és a 2-hidroxipropil-béta-ciklodextrint is. A ciklodextrinek és fehérjék kölcsönhatásával kapcsolatos közzétett eredmények tehát nem pontosan köthetök egy bizonyos cilodextrin típus hatásához. Egy másik, technikai jellegü ok az, hogy a fehérjék stablitásvizsgálata során a stresszelésre/terhelésre alkalmazott módszerek jellegétől függően hol a ciklodextrinek, hol a detergens jellegü stabilizáló adalékok hatékonyak ${ }^{1}$.

A témában folyó kutatómunka intenzitásának illusztrálására az 1. Táblázatban a ciklodextrin fehérje/peptid kölcsönhatásról eddig megjelent közlemények száma látható.

\begin{tabular}{lc}
\hline keresési kulcsszó & publikációk száma * (2017 juniusi adatok) \\
\hline protein & 4500 \\
peptid & 1360 \\
aminosav & 2800 \\
enzim & 1200 \\
chaperone & 155 \\
\hline
\end{tabular}

1. Táblázat A fehérje-ciklodextrin kölcsönhatás irodalmi statisztikája néhány keresési kulcsszó alapján

Az utóbbi évtizedben a korszerü gyógyszerhatóanyagok között rohamosan nőtt a biotechnológiai eszközökkel elöállított terápiás célú peptidek, fehérjék, különféle antitestek aránya. ${ }^{1} \mathrm{~A}$ fehérje-gyógyszerek piaca az elmúlt 10 évben óriási növekedést mutatott, már 2010 es évek elején csak az USA-ban több milliárdos forgalmat jósoltak a 2015 évre. $^{2}$

A fehérje alapú gyógyszerek piacra kerülésének fontos feltétele, hogy a termékek megfelelő stabilitást mutassanak többnyire vizes oldatokban, azaz a terápiás fehérjeszerkezet és farmakológiai hatás biztosítható legyen. A fehérjék érzékeny molekulák, szerkezeti és funkcionális sajátságaik megőrzése a korszerü gyógyszertechnológia komoly kihívása. A jelen összefoglaló közlemény célja a ciklodextrin-technológia lehetőségeinek és korlátainak bemutatása a fehérjék ill. biológiai hatóanyagok formulázásában. 


\section{Mitől különös a ciklodextrin-fehérje kölcsönhatás?}

A ciklodextrinekről régóta ismert, hogy a víznél kevésbé poláris, és megfelelő geometriájú, méretű kismolekulákkal nem-kovalens szupramolekulákat, zárványkomplexeket képeznek. Ezekben a komplexekben az adott vendégmolekula egészben vagy részlegesen foglalja el a ciklodextrin gazdamolekula $\mathrm{kb}$. $1 \mathrm{~nm}$ átméröjű apoláris üregét. ${ }^{3}$ A peptidek, fehérjék esetében ez a gazda-vendég típusú kölcsönhatás azonban sajátosan jelentkezik, mivel a vendégmolekulák mérete sokszorosa a ciklodextrinének. Egy ciklodextrin-fehérje Dávid-Góliát szerü kölcsönhatása során nyilvánvalóan nem történik meg a fehérje molekuláris kapszulázása, hiszen a ciklodextrinek e makromolekulák bizonyos egységeihez, az aromás aminosavakhoz asszociálódnak. Egy ilyen, számítógép segítségével megjelenített „komplexképződést” mutat be az 1. ábra.

A fehérje-ciklodextrin kölcsönhatás molekuláris szinten a ciklodextrin üreg, és/vagy üregfelszín, valamint aromás aminosavak reverzibilis zárványkomplex-képződése révén jön létre ${ }^{4}$. (2. ábra)

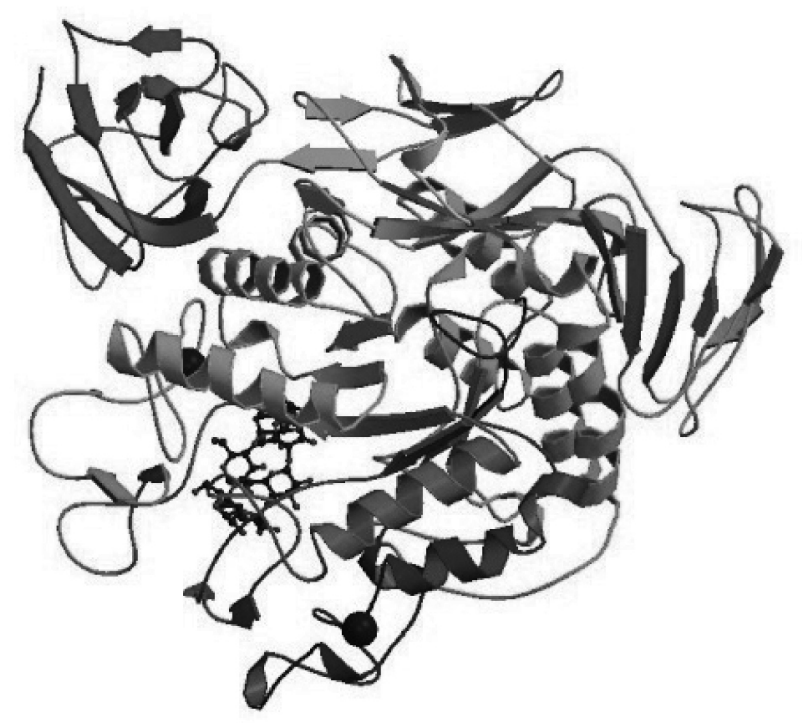

1. ábra Dávid és Góliát: Egy glukoziltranszferáz enzim és a béta-ciklodextrin közötti kölcsönhatás számítógépes modellje ${ }^{5}$
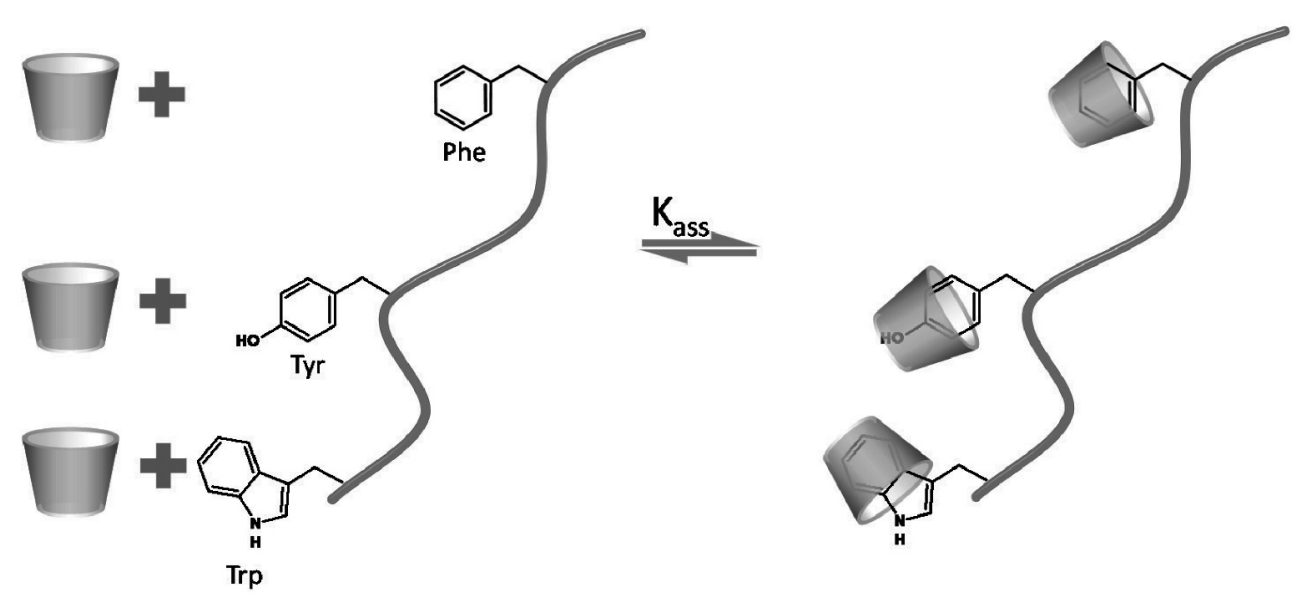

2. ábra A ciklodextrin-fehérje kölcsönhatás sematikus ábrázolása vizes oldatban: az aromás aminosavak ismert komplexképzők ${ }^{4}$

A három gyakorlati jelentőségü alap CD közül az alfa- és a béta-ciklodextrin képes nem-kovalens zárványkomplexek kialakítására aminosavakkal. A komplexképződés mértékét az asszociációs állandóval (Kass) jellemezzük. A fehérjealkotó aminosavak közül az aromás vegyületek (a fenilalanin, a tirozin és a triptofán) zárványkomplex-képzése számottevő (Kass= 100 1/M), az alifás aminosavak közül a leucin gyenge komplexet képez (Kass= 20 1/M), míg a többi alig kimutathatóam lép kölcsönhatásba (Kass= $31 / \mathrm{M})$ vizes oldatban a ciklodextrinekkel. ${ }^{6}$ Hasonló tendencia érvényes a kémiailag módosított ciklodextrinek aminosavakkal képzett komplexeinek stabilitására is. Anionos vagy kationos ciklodextrin-származékok aminosav komplexei esetében nemcsak az üreg és pl. az aromás aminosav-rész, hanem a ciklodextrin felületi töltése és az amino- vagy karboxil-funkciók a vendégmolekula oldaláról is szerepet játszanak a komplex szerkezet stabilizálásában. ${ }^{6} \mathrm{~A} 3$. ábra a deprotonált L-tirozin és a kationos kvaterneramino-bétaciklodextrin komplexének szerkezetét mutatja be NMR vizsgálati eredmények alapján. Jól látható, hogy a zárványkomplex szerkezetének stabilizálásában inklúzió mellett elektrosztatikus és H-hidas kapcsolatok is szerepet játszanak.

Az aminosavak és a különféle átmérőjü királis ciklodextrin üregek között fellépő komplexképződés szinte kínálta a lehetőséget az aminosavak szelektív dúsítására, az aromás és alifás aminosavak egymástól történő elkülönítésére és ezen aminosavak enaniomerjeik elválasztására. A zárványkomplexképzésen alapuló aminosav enantiomer elválasztások mintegy 600 közlemény tárgyát képezik. Különösen bevált az aminosav származékolt (pl. danzilezett, fluorofórral jelölt) formáinak reszolválása ciklodextrinek segítségével. ${ }^{7,8}$ 


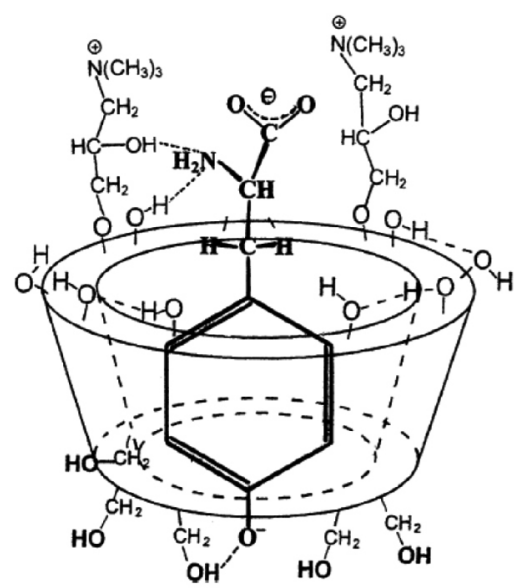

deprotonált L-tirozin és a kvaterner-amino-béta-ciklodextrin 1:1 mólarányú komplexének szerkezete NMR vizsgálok alapján. ${ }^{6}$

Az aminosavak- peptidek, fehérjék és ciklodextrinek komplexképződésére jellemző és gyakorlatban hasznosítható elemek:

- A ciklodextrinek a peptidek/fehérjék hidrofób szakaszaihoz asszociálódnak.

- A kölcsönhatás reverzibilis, klasszikus inklúziós ,gazdavendég" típusú, melyet elektrosztatikus és H-hidas kapcsolat is megerösít.

- A ciklodextrinek oldatban többnyire „dajkafehérje” funkciót láthatnak el, azaz mesterséges chaperonként viselkednek.

- A sok komponensü izomerelegy ciklodextrin származékok molekuláris „kaotrópként” gátolhatják a fehérjék önszerveződését és a rendezettség és aggregáció kialakulását vizes oldatban.

\section{A fehérje-ciklodextrin kölcsönhatás gyakorlati jelentősége}

\subsection{A ciklodextrinek hatása a fehérjék oldékonyságára és aggregációjára}

A fehérjék vizes oldatban bekövetkező aggregációjának csökkentése, megelőzése a biológiai gyógyszerek gyártása és készítménnyé fejlesztése szempontjából egyaránt fontos cél. A biológiai készítményekben az aggregáció következtében a fehérjék transzportja, membránpermeációja és így terápiás hatékonysága is csökken. Emiatt a hatóanyagok farmakokinetikája is megváltozhat. A fehérje monomerek önszervezödése során - egy kritikus aggregátum-méret felett - a fehérjék immunogénné válhatnak, akár anaphylaxist is okozhatnak. Az oldatbani fizikai stabilitás csökkenése a készítmények lejárati idejét és eltarthatóságát csökkentik. A monoklonális antitestek különösen hajlamosak aggregációra, mert számos hidrofób felülettel rendelkeznek, pH 5.0 - 7.5 között a nettó felületi töltésük minimális, így a monomer egységek között nincs elektrosztatikus taszítás. A ciklodextrinekkel biztosítható nem-kovalens, gyenge-közepes komplexképződéssel a fehérjék önszerveződése vizes oldatban elönyösen befolyásolható. A fehérjék zárvány-képződésen alapuló - fizikai és kémiai értelemben vett - stabilizálása a technológiai elönyök mellett iparjogi szempontból is jelentős lehet (,Compositions of matter" típusú életciklus-hosszabbítás).

A ciklosporin, egy természetben elöforduló, 1200 Dalton molekulatömegü, ciklikus peptid, (4. ábra) melynek nagy jelentősége van a szervátültetések gyógyszeres támogatása, az immunoszuppresszió terén. A vízben igen rosszul oldódó hatóanyag formulázása a gyógyszertechnológia régi, ezidáig csak részben megoldott kihívása.

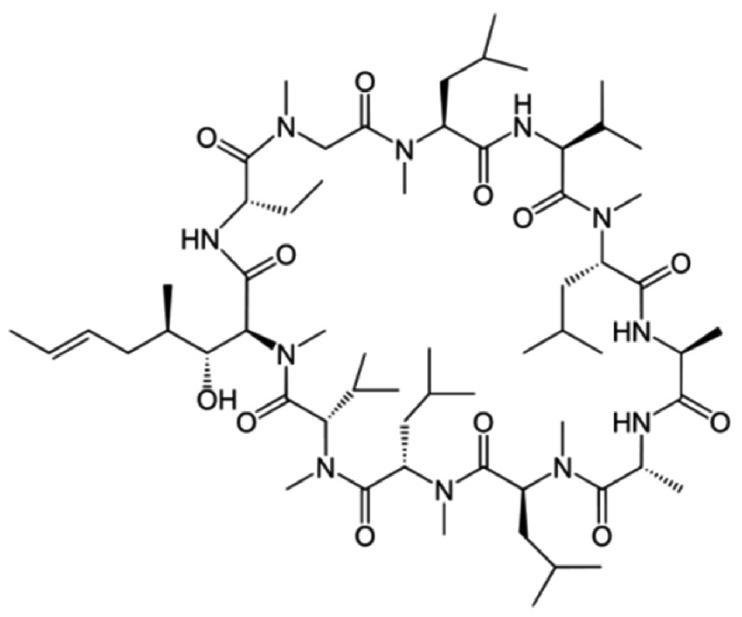

4. ábra Egy terápiás ciklikus peptid, a ciklosporin A szerkezete

A ciklikus peptid rossz vízoldékonyságát detergensek és oldószerek kombinációjával, mikro- és nano-diszperziók előállításával, valamint liposzómális készítményekkel (Neoral ${ }^{\circledR}$, Sandimmun $\left.{ }^{\circledR}\right)$ sikerült fokozni. ${ }^{9}$ A detergens és koszolvens tipusú adalékok ismert háránya, hogy parenterális úton adva az excipiensek számos kellemetlen mellékhatát okoznak. ${ }^{10}$ Japán és finn kutatók ismerték fel elsőként, hogy a ciklosporin vízoldékonysága alfaciklodextrinek, különösen a 2-hidroxipropil-alfaciklodextrin jelenlétében oly mértékben nő, hogy az már a terápiás használhatóságot is biztosítja. ${ }^{11,12}$

A TT-232 jelzésü ígéretes sztomatosztatin analóg hepta-peptid $^{13}$ vizes oldatban fellépő aggregációja metil-béta-ciklodextrinnel hatékonyan gátolható. Az 5. ábra a hepta-peptid aggregációját mutatja pufferben és dimetil-béta-ciklodextrint tartalmazó pufferben, 6 órás keverés után. A hatékony aggregáció-csökkentés és vízoldékonyság-fokozás feltételezett oka, hogy a heptapeptid szerkezetében a három aromás aminosav (D-Phe, D-Trp, Tyr) egyidejü jelenléte tette lehetővé a ciklodextrin dokkolását és egy átmeneti hidrofil molekuláris burok kialakulását.

A fehérjék és peptidek oldékonyságának fokozására és aggregációjuk gátlására ionos ciklodextrinek különösen alkalmasak. A parenterális célra már több termékben engedélyezett anionos beta-CD származék, a szulfobutiléter-béta-CD segítségével sikerült termékké formulázni egy szintetikus tetrapeptid-epoxi ketont, a karfilzomibot. (6. ábra) Ez a vegyület a mieloma egy 
nehezen kezelhető fajtájának gyógyításában játszik fontos szerepet és Kyprolis ${ }^{\circledR}$ néven került forgalomba (AmgenOnyx terméke) Az injekciós liofilizált formulációban $60 \mathrm{mg}$ karfilzomib hatóanyagot $3 \mathrm{~g}$ szulfobutiléter BCD tart oldatban, azaz a peptid: ciklodextrin mólarány $=1: 16$ ).
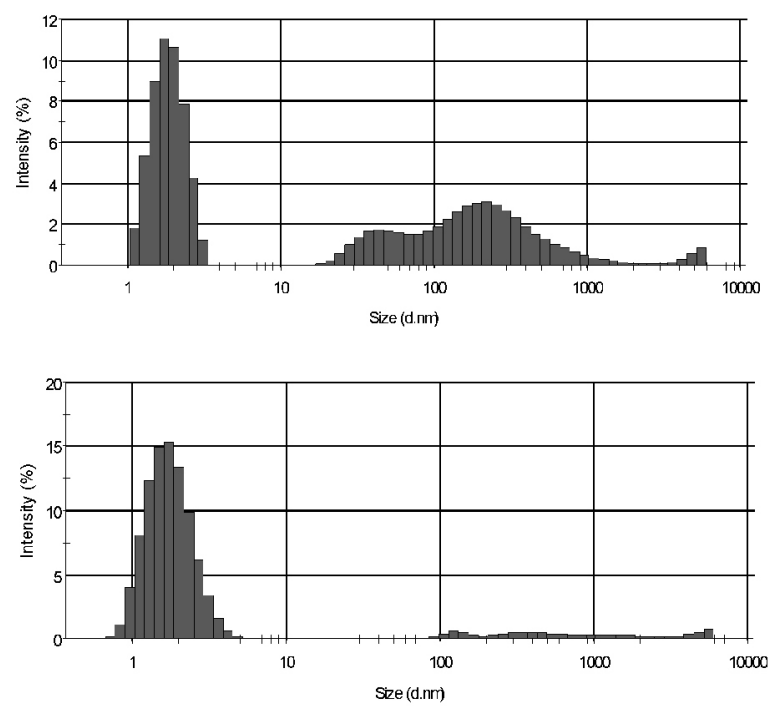

5. ábra A TT-232 szintetikus hepta-peptid aggregációja pufferben (felül) és dimetil-béta-ciklodextrint tartalmazó pufferben (alul) 6 órás keverés után fotonkorrelációs spektroszkópiával (CycloLab nem közölt eredménye)

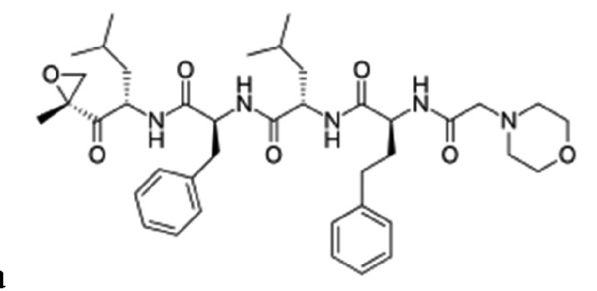

$\mathbf{a}$

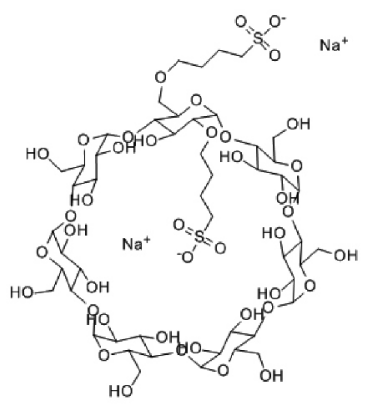

$\mathbf{b}$

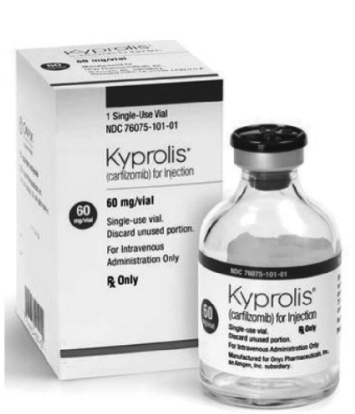

6. ábra Kyprolis ${ }^{\circledR}$ injekció alkotói: a: karfilzomib pepid, b: szulfobutiléter-BCD és c: a Kyprolis ${ }^{\circledR}$ termék
A fehérjék aggregációjának nemcsak a gyógyszerhatékonyság- és stabilitás szempontjából van jelentősége, hanem egyes betegségek kialakulása szempontjából is. Talán legismertebb ilyen patológiás vonatkozású fehérjeszerkezeti változás és aggregáció az időskori neurodegenerációval és az Alzheimer-kórral összefüggésbe hozott jelenség. Nem meglepö, hogy intenzív kutatás folyik a ciklodextrinek és fehérjék kölcsönhatásának e tekintetben történő terápiás felhasználását célozva. Az amyloid peptidek aggregációjának gátlására több ciklodextrin-féleséget is teszteltek. ${ }^{14}$

A leghatékonyabb in vitro aggregáció gátlást koncentrácófüggő módon - a hidroxipropil-béta-CD (HPBCD) mutatta. (7. ábra)

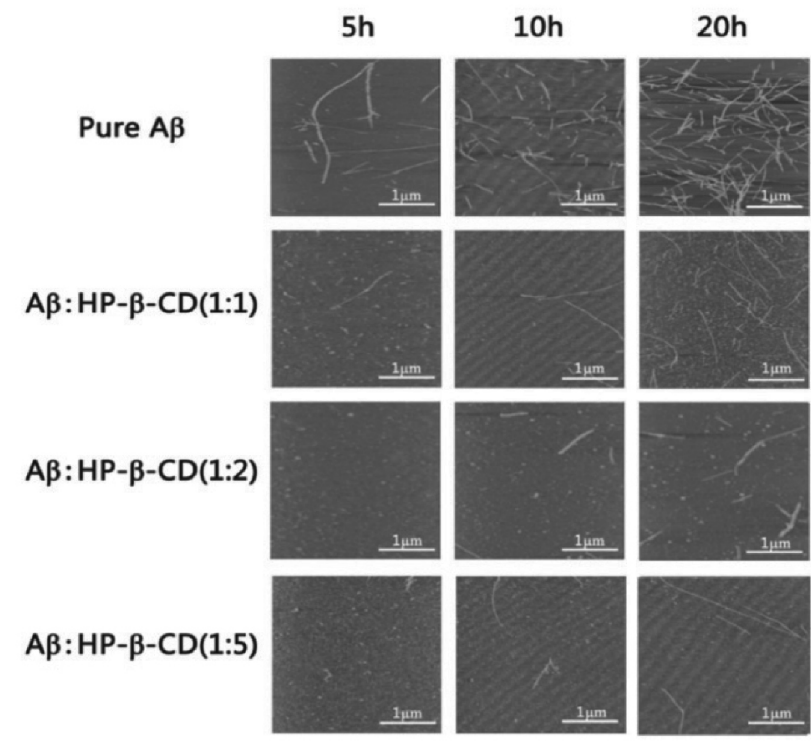

7. ábra AFM felvételek amyloid beta- peptid aggregációjáról HPBCD jelenlétében 5-10-20 órás inkubáció után. ${ }^{14}$

A bíztató in vitro eredményt követően a Weil Cornell egyetem kutatói igazolták, hogy a HPBCD származék amyloid aggregációt gátló hatása in vivo is jelentkezik. ${ }^{15}$

\subsection{Ciklodextrinek a fehérjék stabilizálására}

Irodalmi adatok szerint a ciklodextrinekkel történő fehérje stabilizálás nem általánosan alkalmazható módszer. A kémiai értelemben vett fehérje bomlás gátlására csak bizonyos ciklodextrinek alkalmasak, leggyakrabban az alfaciklodextrint, a hidroxipropil-béta-ciklodextrint, és a metil-béta-ciklodextrint használják e célra. Az immunglobulin G stabilitását hagyományos adalékok (szaharóz, poliszorbát 80) és hidroxipropil-béta-CD mellet vizsgálták. A magas hömérsékleten tartott immunfehérje bomlását a szaharóz, és a detergens is gátolta, de a ciklodextrtin-származék stabilizáló hatását egyik adalék sem érte el. ${ }^{16}$

Az eritropoetin egy 34 kDa molsúlyú glikoprotein, melynek kémiai stabilizálására hidroxipropil-béta- és gammaciklodextrineket alkalmaztak. ${ }^{17}$ A kétféle ciklodextrinszármazék közül a hét tagú, béta-ciklodextrin számottevően jobb stabilizáló hatást mutatott, mint a gamma üregméretü származék. (2. Táblázat) 
2. Táblázat $57^{\circ} \mathrm{C}$-on tárolt eritropoetin formulációk hatóanyag tartalma 10. és 20 . nap után $(\%)^{17}$

\begin{tabular}{ccc}
\hline Stabilizáló adalékok & 10 nap után & 20 nap után \\
\hline kontrol & 40 & 24 \\
HSA 0.25\% & 57 & 30 \\
HPBCD 5\% & 68 & 55 \\
HPBCD 20\% & $\mathbf{1 0 0}$ & $\mathbf{8 8}$ \\
HPGCD 5\% & 46 & 29 \\
HPGCD 20\% & 78 & 36 \\
\hline
\end{tabular}

rövidítések:

HSA: Humán Szérum Albumin,

HPBCD: hidroxipropil-béta-CD,

HPGCD: hidroxipropil-gamma-CD

A fehérjék enzimes bontással szembeni stabilizálását a gyógyszertechnológusok a szájon át szedhető fehérjekészítmények kifejlesztése céljából vizsgálják. Az emésztőrendszer fehérjebontó enzimjei müködésükkel gátolják orális biológiai készítmények fejlesztését. A ciklodextrinek e tekintetben történő alkalmazása sem ígér túl sokat. Kezdeti biztató eredményeket közöltek terápiás peptidek pl. [D-Trp6, des-Gly10] LHRH etilamid, vagy deszlorelin kimotripszinnel szembeni stabilizálásáról. ${ }^{18} \mathrm{Az}$ eznimesen módosított ciklodextrinek közül a maltozil-béta-ciklodextrint találták hatékony stabilizálószernek, mely a buzerelin-acetát antiandrogén-hatású peptidet és a sárgatest-képződést serkentő (LHRH) hormont védte az alfa-kimotripszin támadásával szemben. ${ }^{19}$

\section{Különleges ciklodextrin-fehérje kölcsönhatások: ciklodextrinek és a pórusképző fehérjék}

A ciklodextrinek és fehérjék közötti kölcsönhatás különös esete, amikor a ciklodextrin maga helyezkedik el egy fehérje pórusban (csatornában) és az ott zajló folyamatokat jelenlétével befolyásolja. A természetben előforduló pórusképző fehérjék pl. egyes baktérium exotoxinok, egy sejtmembrán lipid kettősrétegébe ágyazódva, ott önszerveződve, alakítanak nanoméretű csatornát. Ezeken a pórusokon többnyire bakteriális toxinokat juttatnak a recipiens sejtbe, így azokat elpusztítják. ${ }^{20} \mathrm{E}$ különleges fehérje-ciklodextrin kapcsolatnak és a molekuláris „pórusszűkítésnek” két gyakorlati szempontból fontos terápiás vonatkozása van:

- Újszerü antibiotikus terápia lehetősége: a baktérium toxinok sejtbe jutásának megakadályozása;

- Valós idejü, automatizált és költséghatékony DNS szekvenálási diagnosztikai eszköz fejlesztése.

Újszerü antibiotikus terápia lehetősége: Ez esetben nem a baktériumok elpusztítása a cél, hanem a baktrériumok virulenciájának és toxintranszportjainak csökkentése, megakadályozása. Az újszerü antibiotikus terápiás elvet a 8 . ábra szemlélteti. ${ }^{21}$

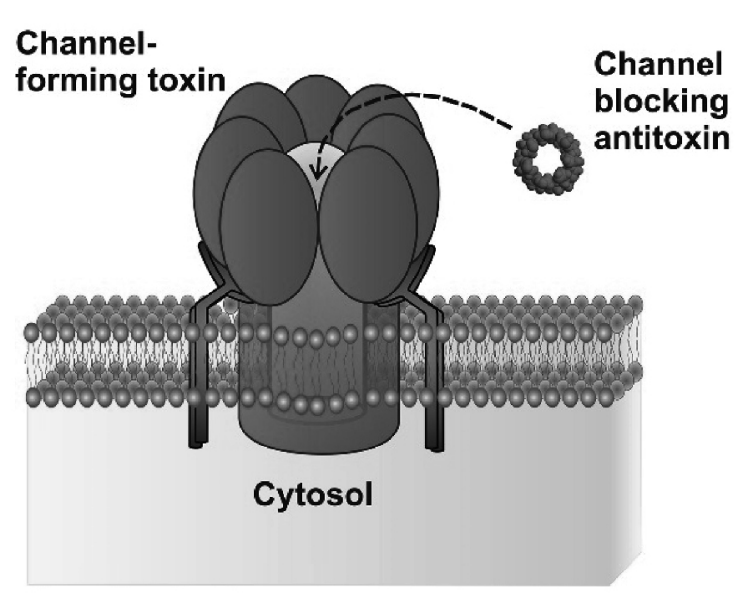

8. ábra A lépfene (Anthrax) bacillus fertőzőképessége csökken a bakteriális toxinok transzportjának cilodextrin által történő gátlásával. ${ }^{21}$

Valós idejü, automatizált DNS szekvenálási technika: Az újszerü, ciklodextrinnel segített szekvenálási elvet Hagan Bayley és munkatársai dolgozták ki. ${ }^{22,23}$

Az alfa-hemolizin fehérjepórusán keresztüli iontranszport tanulmányozásakor alakult ki az elképzelés, hogy a fehérjepórusba ültetett - molekuláris felismerőképességgel rendelkező - nanogyürü pl. egy ciklodextrin, lehetővé teszi a szükített póruson áthaladó molekulák azonosítását. (9. ábra)
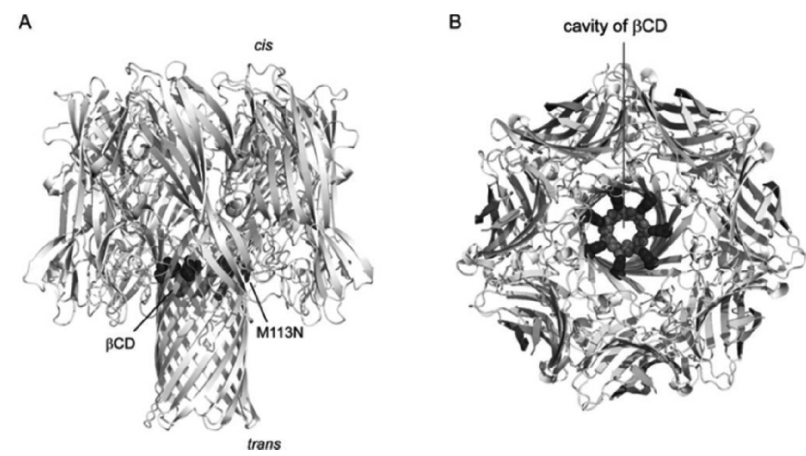

9. ábra Az alfa hemolizin és benne ülő ciklodextrin sematikus szerkezete A: szemből nézve, B: felülről nézve ${ }^{21}$.

A fenti „gyürü a pórusban” típusú molekuláris elrendezés alapján fejlesztett valós idejü DNS szekvenálási folyamat az alábbi lépésekből áll:

- szigetelő szilikonrétegbe ágyazott hemolizin fehérjepórus, benne a ciklodextrin olvasófejjel, melyen folyamatos ionáram halad át;

- a mintaelőkészítés: a DNS mintát egy exonukleáz enzim hasítja bázisokká;

- az enzim által lehasított nukleinsav töredék a szükített nanopóruson áthaladva az olvasófej CD-hez ér, ott lassul ill. megáll, attól függően, mekkora affinitása van a ciklodextrinhez, ezzel az ionáramot megszakítja (minden nukleinbázis sajátos, jellemző megszakítási jelet ad). 
Az Oxford Nanopore Technologies nevü vállalat a fenti elven alapulva már piacra vitte a Minion nevü termékét, melyet 2014 óta folyamatosan használnak gyors, költséghatékony DNS szekvenálási diagnosztikai célra. (10 ábra)

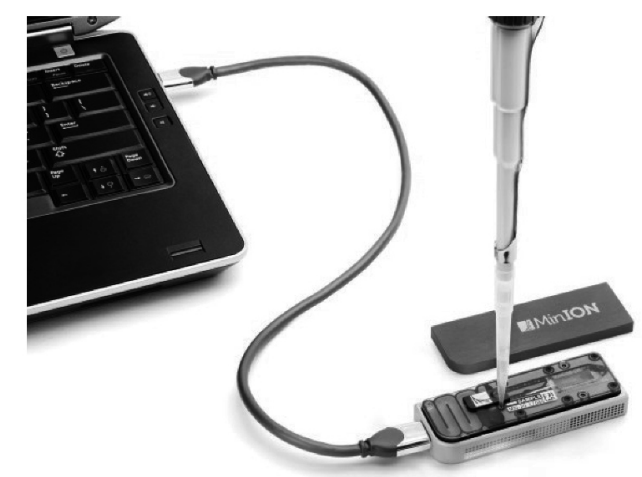

10. ábra MinION® lap top géphez csatlakoztatva (Oxford Nanopore Technologies)

\section{Irodalmi hivatkozások:}

1. Charman, S.A.; Mason, K.L.; Charman, W.N. Pharm. Res., 1993, 10(7), 954-962.

https://doi.org/10.1023/A:1018994102218

2. SBWire: Global protein drugs market 2017 http://www.sbwire.com/press-releases/global-protein-drugsmarket-2017-eli-lilly-ucb-group-genentech-johnsonjohnsonnovo-nordisk-biogen-idec-amgen-877609.htm

3. Szejtli, J. Cyclodextrin Technology, Kluwer Academic Publ. Dordrech, Holland, 1988. Pp.1-13.

http://www.springer.com/us/book/9789027723147 https://doi.org/10.1007/978-94-015-7797-7 1

4. Szejtli, J.; Szente, L.; Specht, M. Treatment of protein hydrolyzates to remove phenylalanine. Ger. Offen. DD 14761515 Apr 1981, Chem. Abstr. 1981, 95, 202298.

5. Schmidt, A.K., Cottaz, S., Driguez, H., Schulz, G.E. Biochem. 1998, 37, 5909-5915. https://doi.org/10.1021/bi9729918

6. Sebestyén, Z; Buvári-Barcza, A; Rohonczy, J. J. Incl. Phenom. Macrocycl. Chem. 2012, 73(1-4), 199-210. https://doi.org/10.1007/s10847-011-0043-2

7. Jin, H.L.; Stalcup, A.; Armstrong, D. W. Chirality, 1989, 1(2), 137-141. https://doi.org/10.1002/chir.530010207

8. Sun, X.; Li, D.; Lee, M.L. Anal. Chem. 2009, 81(15), 62786284. https://doi.org/10.1021/ac9001832

9. Trull, A.K.; Tan, K.K.; L.; Tan, L.; Alexander, G.J.; Jamieson, N.V Brit. J. Clin. Pharmacol. 1995, 39, 627-631. https://doi.org/10.1111/j.1365-2125.1995.tb05722.x

10. Boukhris, T.; Lahiani-Skiba, M.; Martin, D.; Skiba, M. $J$ Incl. Phen. Macrocyclic Chem. 2013, 75, 323- 332. https://doi.org/10.1007/s10847-012-0189-6

11. Miyake, K.; Hirayama, F.; Uekama, K. J. Pharm. Sci. 1999, 88(1), 39-45. https://doi.org/10.1021/js980284+

12. Matilainen, L.; Jaervinen, K.; Toropainen, T.; Naesi, E.; Auriola, S.; Jaervinen, T.; Jarho, P. Int. J. Pharm. 2006, 318(1-2), 41-48. https://doi.org/10.1016/j.ijpharm.2006.03.009

\section{5. Összefoglalás}

A fehérje-CD kölcsönhatás intenzíven kutatott (biológiai hatóanyagok/bioszimilárisok).

- Az első ciklodextrinnel formulázott peptid hatóanyagú gyógyszer, a Kyprolis ${ }^{\mathrm{TM}}$ (Amgen) már piacon van.

- Egy speciális fehérje-CD kölcsönhatáson alapuló diagnosztikai alkalmazás is megvalósult: az Oxford Nanopore termékei : Minion ${ }^{\mathrm{TM}}$, piacra kerültek.
13. Tejeda, M.; Gaál, D.; Hullán, L.; Schwab, R., Szokolczi, O., Kéri, Gy. Anticancer Res. 2007, 4015-4019. PMid:18225564

14. Ren, B.; Jiang,. B.; Hu. R.; Zhang, M.; Chen. H.; Ma, J.; .Sun, Y.; Jia, L.; Zheng. J. Phys. Chem. Chem. Phys. 2016, 18(30), 20476-20485. https://doi.org/10.1039/C6CP03582E

15. Yao, J.; Ho, D.; Calingasan, N.Y.; Pipalia, N.H.; Lin, M.T.; Beal, M.F. J. Exp. Med. 2012, 209 (13), 2501-2513. https://doi.org/10.1084/jem.20121239

16. Hartl, E.; Dixit, N.; Besheer, A.; Kalonia, D.; Winter, G. Eur. J. Pharm. Biopharm. 2013, 85, 781-789. https://doi.org/10.1016/j.ejpb.2013.04.021

17. Konings, F.J.; Noppe, M.J.M.; Mesens, J.L.Patent WO 9111200 A1 8 Aug 1991, US Pat. 5,376,632, Chem. Abstr. 1991, 115, 189805.

18. Koushik K.N.; Bandi N.; Kompella U.B. Pharm. Dev. Technol. 2001, 6(4), 595-606. https://doi.org/10.1081/PDT-120000297

19. Matsubara, K.; Ando, Y.; Irie, T.; Uekama, K. Pharm. Res. 1997, 14(10), 1401-1405. https://doi.org/10.1023/A:1012120705408

20. Karginov, V.A.; Nestorovich, E.M.; Moayeri, M.; Leppla, S. H.; Bezrukov, S.M. Proc.Nat. Acad. Sci. USA, 2005, 102 (42), 15075-15080. https://doi.org/10.1073/pnas.0507488102

21. Karginov, V.A.; Yohannes, A.; Robinson, T.M.; Fahmi, N.; Eddine, A.K.; Hecht, S.M. Bioorg. Med. Chem. 2006, 14(1), 33-40. https://doi.org/10.1016/j.bmc.2005.07.054

22. Gu, L.; Braha, O.; Conlan, S.; Cheley, S.; Bayley, H. Nature 1999, 398(6729), 686-690. https://doi.org/10.1038/19491

23. Gu, L.; Cheley, S.; Bayley, H. Science 2001, 291(5504), 636-640. https://doi.org/10.1126/science.291.5504.636 


\section{Protein - Cyclodextrin Interaction in Therapy and Diagnostics}

The interaction between cyclodextrins (CDs) and proteins has been known for decades and subject of over 4000 papers. Despite the large number of literature data often contradictory results are reported, no generally valid conclusions have been drawn from these non-covalent molecular interactions. The present paper attempted to show the possibilities and limits of utility of CD technology in formulation of proteins.

Cyclodextrins are cyclic oligosaccharides. Three representatives: alpha-, beta- and gamma-CDs, consisting of 6, 7 and 8 glucose units, resp. can be found in the nature. The industry responded to the growing demand by increasing the production: nowadays CDs are produced in ten thousands of tons yearly. Even some derivatives, such as hydroxypropyl, random methylated and sulfobutyl beta-CD are produced in large quantities.

There are several cyclodextrin-containing products available. More than 60 human and 10 veterinary drug formulations, hundreds of products of the food, cosmetic and toiletry industry have been marketed.

Most of these applications are based on complexation of small molecules (the molecular weight falls in the range of 200-700 Dalton). In the modern biotechnology, however, the active compounds are of larger size and larger molecular weight. The proteins with therapeutic effect are characterized with 2000-300000 Dalton molecular weight. These molecules need different approach. The main challenge is the stability that is the preservation of the original structure and functionality in the pharmaceutical formulation.

\section{Why CD-protein interactions are so peculiar?}

It is well-known that CDs form inclusion complexes with low-polarity small molecules. The guest molecules occupy the cavity of CDs in these non-covalent supramolecules. The diameter of the cavity is less than $1 \mathrm{~nm}$. The peptides and proteins, however are large molecules, much larger than the CDs. This is a David-Goliath interaction. As shown in Fig. 1 CDs associate to certain units of proteins only, these are the aromatic amino acids. The protein-CD interaction is realized through the reversible inclusion complex formation between the aromatic amino acids, such as phenylalanine, tyrosine and tryptophane and CDs. (Fig. 2) Among the three natural CDs alpha- and beta-CD are able to form inclusion complexes with these aromatic amino acids. The degree of complex formation is characterized by the complex association constant (Kass). The aromatic amino acids form complexes with CDs in a high extent (Kass $=1001 / \mathrm{M})$, leucin in a lower extent (Kass $=201 / \mathrm{M}$ ), while the other aliphatic amino acids show hardly any interaction with the CDs (Kass $=31 / \mathrm{M}){ }^{6}$ Similar trends are observed for the $\mathrm{CD}$ derivatives, too. In the case of anionic and cationic $\mathrm{CD}$ derivatives not only the hydrophobic interactions between the aromatic moiety of the amino acid and the cavity but also the surface charge provided by the amino and carboxyl functions play a role in the stabilization of the complex.

Fig. 3 shows the structure of tyrosine complexed by quaternary amino beta-CD as determined by NMR.

The chiral CD cavity offers the possibility of enantiorecognition utilized for the selective concentration and separation of amino acid enantiomers described in approx.. 600 scientific papers. Especially the derivatized (dansylated, labeled with fluorophore) amino acids can be resolved by using CDs. ${ }^{7,8}$

The main characteristics of the peptide/protein-CD interactions are as follows:

- CDs associate to the hydrophobic parts of the peptides/proteins.

- The interaction is reversible, the classical "host-guest" interaction is reinforced by electrostaticforces and H-bonding.
- CDs function as chaperon.

- CD derivatives are mixtures of isomers, which as "chaotropic agents" can inhibit the self-organization, aggregation of proteins in aqueous solutions.

\section{Practical importance of protein-CD interaction}

The main objective in the development and production of biological drugs is the reduction of aggregation in aqueous solution. The proteins in aggregated form behave differently compared to their monomeric form, their transport, membrane permeation and with this also the therapeutic effect are changed. The large aggregates can be immunogenic and may cause anaphylaxis. The low stability results in reduced durability and short expiry period. The complex formation with CDs can control the self-aggregation. Further advantage may lay in IP rights also. Cyclosporine is a natural cyclic peptide of 1200 Dalton molecular weight. (Fig. 4) It is used as an immunosuppressant in organ transplantations. This drug has poor aqueous solubility which was improved by combination of solvents and detergents, micro- and nanodispersions, and liposomes (Neoral ${ }^{\circledR}$, Sandimmun $\left.{ }^{\circledR}\right)$. These formulations, however, have several side-effects. ${ }^{9}$ Japanese and Finnish researchers recognized first that the solubility of cyclosporine can be improved to the therapeutically desired level by alpha-CD, especially with hydroxypropyl alpha-CD (HPACD). The aggregation of TT232, a stomatostatin analog heptapeptide, can be effectively hindered by methyl beta-CD. Fig. 5 shows the aggregation of the peptide in buffered aqueous solution (top) and in the presence of dimethyl beta-CD (bottom) after $6 \mathrm{~h}$ of stirring. The enhanced aqueous solubility and reduced aggregation are attributed to the cyclodextrin complexation of the three aromatic amino acids (D-Phe, D-Trp, Tyr) creating a provisional hydrophilic molecular wrapping.

The CDs with ionic functionalities are especially useful for enhancing the solubility and reducing the aggregation of proteins and peptides. Carlfilzomib, a synthetic tetrapeptide-epoxy ketone was formulated by anionic $\mathrm{CD}$ derivative, sulfobutylether beta-CD (SBEBCD) and marketed under the trade name of Kyprolis ${ }^{\circledR}$ (the product of Amgen-Onyx). (Fig. 6) In the lyophilized formulation for injection $60 \mathrm{mg}$ carlfilzomib is solubilized by $3 \mathrm{~g}$ SBEBCD corresponding to 1:16 molar ratio.

It is intensively investigated if the aggregation-suppressing effect of CDs can be utilized in various diseases, such as neurodegeneration with aging and Alzheimer diseases. Several CDs were studied for hindering the aggregation of amyloid peptides. ${ }^{14}$ HPBCD was the most effective (Fig. 7)

CDs improve the stability of proteins against the effect of heat. Table 2 shows that HPBCD could effectively preserve the protein erythropoietin content upon storage at elevated temperature for 10 and 20 days.

Peculiar protein-CD interactions can be observed with the pore-forming proteins. CDs behave as gatekeepers (Fig. 8 and 9), which can be utilized for:

- hindering the entrance of the bacterial toxins into the cells (antibiotic effect)

- developing real time, automated, cost-effective DNA sequencing device.(Fig. 10)

As a conclusion the importance of protein-CD interactions are shown by the fact that currently two marketed products are related to these interactions:

- An injectable anticancer drug under tradename of Kyprolis $^{\mathrm{TM}}$ by Amgen,

- A real time DNA sequencing device under the name Minion $^{\mathrm{TM}}$ by Oxford Nanopore. 